\title{
Biological water treatment in a recirculating aquaculture system
}

\author{
Evelin-Anda Laza ${ }^{1 *}$, Ioan Ladislau $\mathrm{Caba}^{1}$, Mihai Olan ${ }^{1}$, and Valentin Vladut ${ }^{1}$ \\ ${ }^{1}$ National Institute of Research - Development for Machines and Installations designed to Agriculture \\ and Food Industry - INMA, Bucharest 013813, Romania
}

\begin{abstract}
Biological water filtration is a process by which toxic compounds are removed from water using organisms. A well-sized biological filter is extremely important as part of a recirculating aquaculture system for fish farming. Biological water filtration equipment in aquaculture recycling systems is a technological set that restores the vital qualities of wastewater from fish ponds, thus allowing its reuse
\end{abstract}

\section{Introduction}

Biological water filtration equipment in recirculating aquaculture systems is a technological set that restores the vital qualities of wastewater from fish ponds and allowing its reuse. Biological filters include a filtration technique that uses living organisms to remove a number of toxic compounds from the water and is intended to neutralize ammonia and nitrites in recirculating aquaculture systems (RAS) for superintensive fish farming[1,6,7].

The main technological desideratum to be achieved in a SAR is to ensure medial conditions that correspond, to the greatest extent possible, to the ecophysiological particularity of the crop species $[2,4,5]$. The decomposition of nitrogen compounds is of

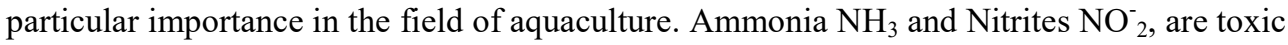
substances for fish. Nitrates $\mathrm{NO}_{3}^{-}$, are also toxic when they accumulate in high concentrations. With the help of Nitrosomonas bacteria, ammonium is converted into nitrites $\mathrm{NO}_{2}^{-}[2,3,6]$

The next phase under the action of other types of Nitrobacter bacteria, the nitrites resulting in the first phase are transformed into nitrates $\mathrm{NO}_{3}^{-}$, because nitrates can also become toxic when they accumulate in a large amount, it is recommended to limit the bacterial conversion $\mathrm{NH}_{4}^{+} \rightarrow \mathrm{NO}_{3}^{-}[2,3,6]$.

Water from recirculating aquaculture system can come from cattle farm if are advanced electrochemical treatment [8] or various other sources of recovered water [9], using smart system to monitor wastewater treatment [10].

Figure 1 describes the characterization of nitrification and denitrification processes that take place during the process of biological filtration of water

\footnotetext{
* Corresponding author: eveline_anda@yahoo.com
} 


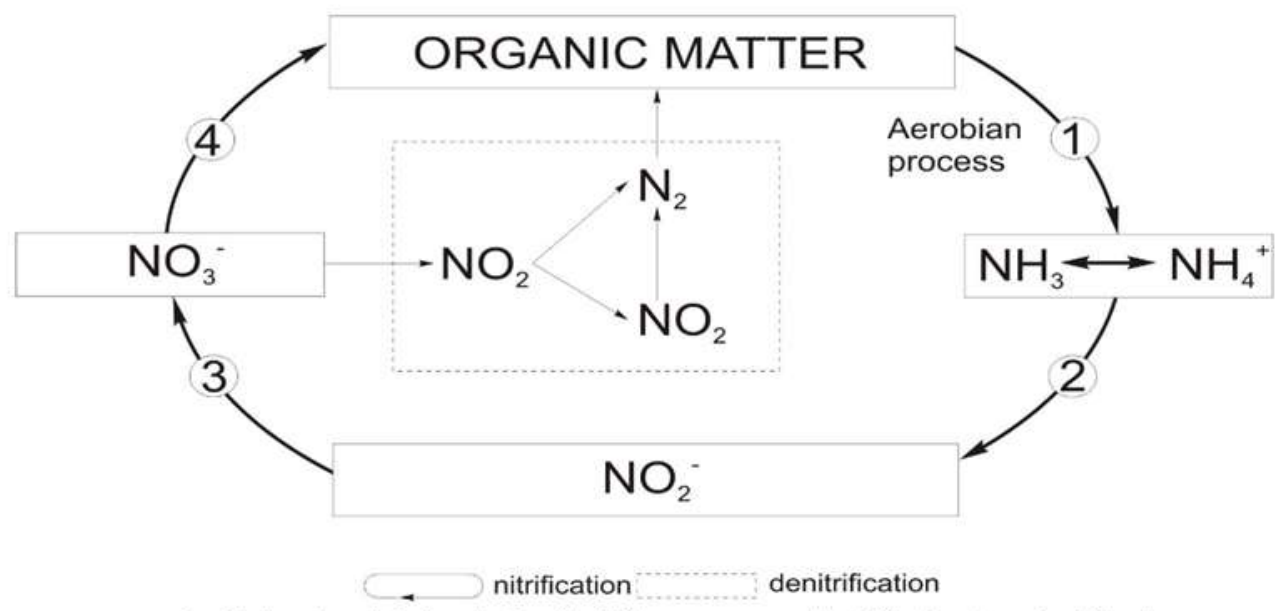

1 - Heterotrophic bacteria; 2 - Nitrosomonas; 3 - Nitrobacter; 4 - Plants

Fig.1. Characterization of nitrification and denitrification processes that take place during the process of biological filtration of water

In figure 2 a biological filter can be seen and figure 3 shows the aeration system of the biological filter.

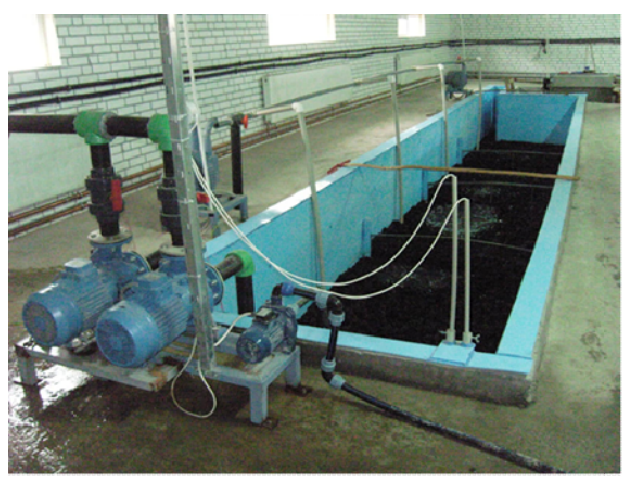

Fig.2 Biological filter with ball

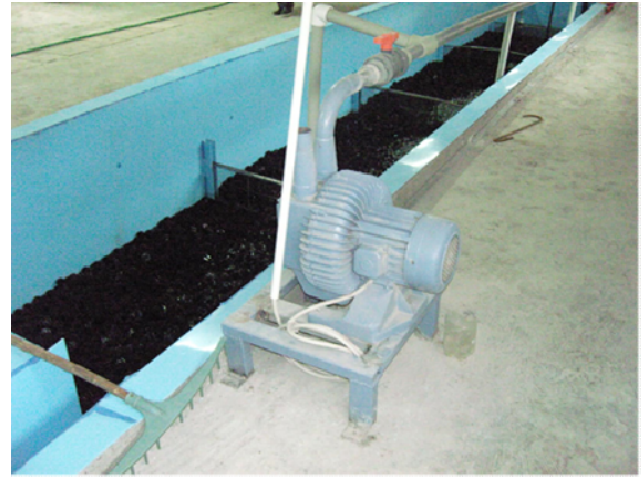

Fig.3 Aeration system of the biological filter

\section{Methodology}

Figure 4 represents the technological scheme of a recirculating aquaculture system, in which the position of the biological filter can be observed. 


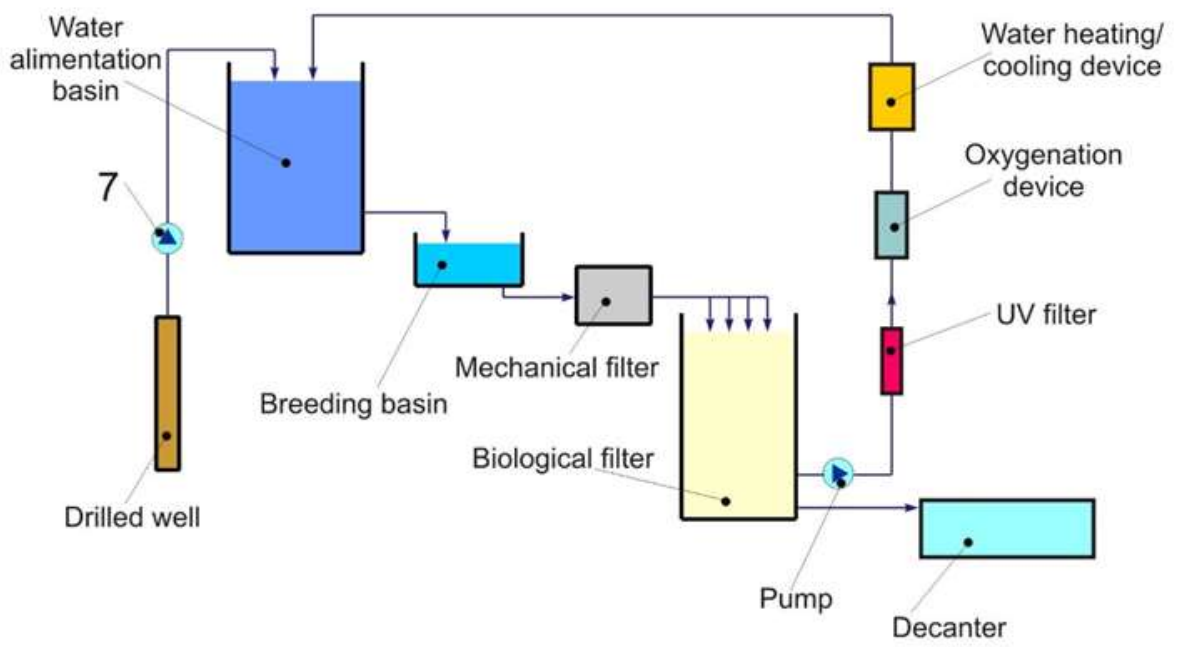

Fig. 4 Water circulation scheme in a recirculating aquaculture system

The biological filter on which the experimental determinations were made was supplied with wastewater from fishs basins through the exhaust connection on the top of an outer wall. Wastewater drains gravitationally through the upper grate, the filter element layer and the lower grate in the first cavity of the filter, passes through the slot provided for this purpose in the second cavity, after which, due to the principle of communicating vessels, passes up, in turn through the grate bottom, the filter element layer and the upper grill, reaching the discharge opening.

Biological filtration of water takes place during its passage through the layers of filter element, which are made of round plastic supports populated with aerobic bacteria.

For a good functioning of the biological filter, it is necessary to produce a strong aeration of the water, and in some situations also its additional oxygenation. These operations are performed by insufflating air and oxygen, respectively, under pressure, in the exhaust connection provided for it, which reaches the water in dispersed form, with the help of diffusers. Sediments deposited on the bottom of the biological filter cavities are evacuated by periodic purging.

The measurement of water temperature, $\mathrm{pH}$ level and dissolved oxygen was performed for each sample taken in order to perform physico-chemical analyzes of water, in order to individualize each sample and to monitor the influence of these factors on the quality of biological filtration. The quality parameters of water after the biological treatment will be by taking water samples before and after the biological filtration process.

Figure 5 shows the flow of water in the biological filter 


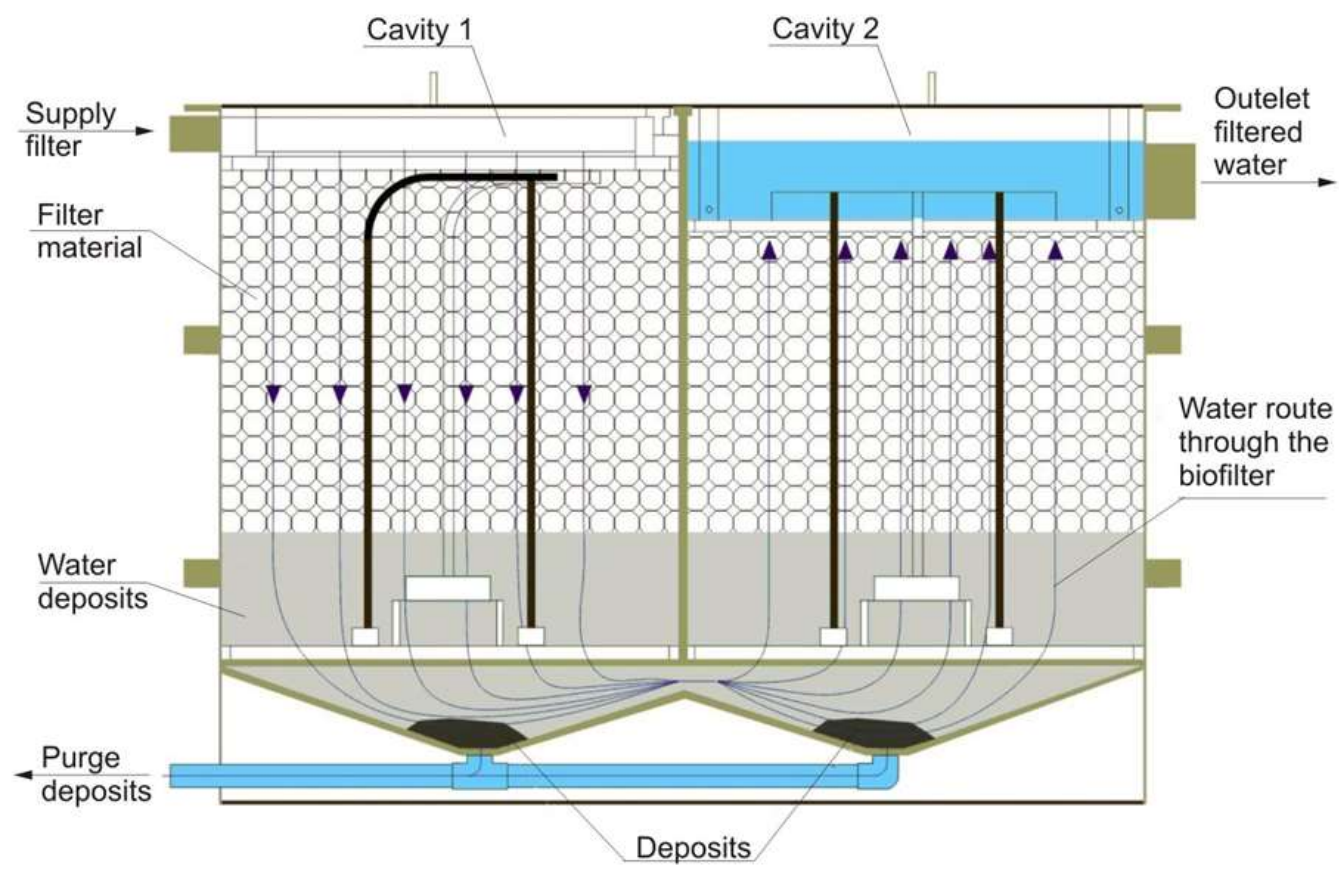

Fig.5 The water flow in the biological filter

The flow rates of filtered water with which each basin was supplied separately were determined by timing the flow (in seconds) of ten liters of water and making the ratio:

$$
\mathrm{Q}_{\mathrm{n}}=600 / \mathrm{t}_{\mathrm{n}}[1 / \mathrm{min}]
$$

In this way the following results were obtained:

$$
\begin{aligned}
& \mathrm{t}_{1}=5 \mathrm{~s} \\
& \mathrm{t}_{2}=5 \mathrm{~s} \\
& \mathrm{t}_{3}=11 \mathrm{~s} \\
& \mathrm{t}_{4}=11 \mathrm{~s} \\
& \mathrm{t}_{5}=11 \mathrm{~s} \\
& \mathrm{t}_{6}=40 \mathrm{~s}
\end{aligned}
$$

$$
\begin{aligned}
& \mathrm{Q}_{1}=150 \mathrm{l} / \mathrm{min} \\
& \mathrm{Q}_{2}=150 \mathrm{l} / \mathrm{min} \\
& \mathrm{Q}_{3}=60 \mathrm{l} / \mathrm{min} \\
& \mathrm{Q}_{4}=60 \mathrm{l} / \mathrm{min} \\
& \mathrm{Q}_{5}=60 \mathrm{l} / \mathrm{min} \\
& \mathrm{Q}_{6}=15 \mathrm{l} / \mathrm{min}
\end{aligned}
$$

\section{Results and discussions}

As it was found, the flow thus determined falls within the range of $30 \ldots 50 \mathrm{~m} 3 / \mathrm{h}$ of the maximum flow provided for the biological filter.

$$
\mathrm{Q}=570 \mathrm{l} / \mathrm{min}=34,2 \mathrm{~m}^{3} / \mathrm{h}
$$

The useful volume of the biological filter, defined as the volume occupied by the filter element, was determined by measuring the thickness of the filter element layer in the two filter cavities, which was multiplied by the section of the cavities. 


$$
\mathrm{V}_{\text {usfl }}=\mathrm{S}_{1} \mathrm{xh}_{1}+\mathrm{S}_{2} \mathrm{xh}_{2}
$$

Where they were measured:

$$
\begin{aligned}
& \mathrm{S}_{1}=\mathrm{S}_{2}=1,47 \times 0,9775=1,437 \mathrm{~m}^{2} \\
& \mathrm{~h}_{1}=0,87 \mathrm{~m} \\
& \mathrm{~h}_{2}=0,80 \mathrm{~m}
\end{aligned}
$$

The total volume of the two cavities of the biological filter is $3.75 \mathrm{~m}^{3}$, which means that the useful volume occupies $64 \%$ of the total volume. The remaining $36 \%$ is occupied by water, air, deposits and grills.

The air flow blown into the biological filter was determined by measuring with a thermo-anemo-manometer using a Pitot tube.

The flow determined by the air blown into the biological filter through the two diffusers provided for this purpose was $5.5 \mathrm{~m}^{3} / \mathrm{h}$

The flow of blown oxygen was determined using the flow meter belonging to the oxygen distribution system of the recirculating aquaculture system, provided for this purpose at the entrance to the biological filter. This flow depends on the oxygen pressure and can be adjusted with the help of a valve when the maximum opening of the oxygen reached $81 / \mathrm{min}$. Due to the high costs required by the oxygen supply, the use of oxygen is only used if the aeration does not meet the requirements, especially in the hot summer months.

The determination of the purged water flow was performed by opening the purge valve to the maximum and timing the flow of 10 liters of water with deposits, the following results were obtained: $\mathrm{tp}=25 \mathrm{~s}$, and we got the result:

$$
\mathrm{Q}_{\mathrm{p}}=24 \mathrm{l} / \mathrm{min}=1,44 \mathrm{~m}^{3} / \mathrm{h}
$$

The determination of the water temperature, the $\mathrm{pH}$ level and the dissolved oxygen was performed for each sample taken in order to perform the physico-chemical analyzes of the water, in order to individualize the sample and to be able to follow the influence of these factors on the quality of biological filtration. The determination of water temperature, $\mathrm{pH}$ level and dissolved oxygen was performed with C863 Electrochemical Multimeter, using the probes provided.

The quality parameters of water after the biological treatment were measured before and after the biological filtration process.

The results in table 2 show the values of the parameters of water before the biological filtration.

Table 1 Parameters of water before the biological filtration

\begin{tabular}{|c|l|c|c|}
\hline $\begin{array}{c}\text { Crt. } \\
\text { no }\end{array}$ & \multicolumn{1}{|c|}{ Physico-chemical parameter } & M.u. & Measured values \\
\hline 1. & pH & upH & 7,8 \\
\hline 2. & Oxygen & $\mathrm{mg} / 1$ & 5 \\
\hline 3. & Ammonia $\left(\mathrm{NH}_{3}\right)$ & $\mathrm{mg} / \mathrm{l}$ & 0,06 \\
\hline 4. & Nitrates $\left(\mathrm{NO}_{3}^{-}\right)$ & $\mathrm{mg} / \mathrm{l}$ & 0,6 \\
\hline 5. & Nitrites $\left(\mathrm{NO}_{2}^{-}\right)$ & $\mathrm{mg} / \mathrm{l}$ & 0,4 \\
\hline 6. & Ammonium $\left(\mathrm{NH}_{4}^{+}\right)$ & $\mathrm{mg} / 1$ & 0,03 \\
\hline
\end{tabular}


The water parameters have normal values for the water in fish basins and nitrogen compounds are approaching the limit. By analyzing the water after the biological filtration and determining the physico-chemical parameters, the following values resulted:

Table2 Parameters of water after the biological filtration

\begin{tabular}{|c|l|c|c|}
\hline $\begin{array}{c}\text { Crt. } \\
\text { no }\end{array}$ & \multicolumn{1}{|c|}{ Physico-chemical parameter } & M.u. & Measured values \\
\hline 1. & pH & upH & 7,5 \\
\hline 2. & Oxygen & $\mathrm{mg} / 1$ & 4,5 \\
\hline 3. & Ammonia $\left(\mathrm{NH}_{3}\right)$ & $\mathrm{mg} / 1$ & 0,01 \\
\hline 4. & Nitrates $\left(\mathrm{NO}_{3}^{-}\right)$ & $\mathrm{mg} / 1$ & 0,2 \\
\hline 5. & Nitrites $\left(\mathrm{NO}_{2}^{-}\right)$ & $\mathrm{mg} / 1$ & 0,1 \\
\hline 6. & Ammonium $\left(\mathrm{NH}_{4}^{+}\right)$ & $\mathrm{mg} / 1$ & 0,0 \\
\hline
\end{tabular}

After the water analysis it was found that the biological water filtration process was efficient and that the water parameters reached optimal values for the good development of the fish.

\section{Conclusion}

Following the biological filtration of water the following conclusions were found:

- the working regime of the biological filter can vary greatly, depending on a number of factors, such as: the species of fish raised in the ponds, its age and density in the ponds, the type and amount of feed, the water temperature, its $\mathrm{pH}$, quality of aeration and /or oxygenation;

- the nitrification process is a process with high oxygen consumption, it is important to ensure additional aeration of the water;

- due to the low passage of water, fine solid impurities in the water were deposited on the bottom of the basins. By periodically opening the purge valve (once every 24 hours, or as many times as necessary), these impurities have been removed to the channel;

- because atypical situations can occur occur, especially on hot summer days, when the biological activity of fish is more intense, given the importance of reconditioning the water that feeds the fish basins, it is recommended that the biological filter be slightly oversized.

Acknowledgement: The work has been funded by the Sectorial Programme MADR ADER 2019-2022, ADER 25.3.1. Recirculating aquaculture systems used in the stage preceding the repopulation of natural waters with fish material, Contract no. ADER 25.3.1 / 24.09.2020/ AA 2 / 11.05.2021.

\section{References}

[1]. Avnimelech Y. Bio-filters The need for an new comprehensive approach, Aquacultural Engineering, Elsevier, vol. 34 (3), (2005)

[2]. Andrei S.G., Pop A., David E., Ştefanov C. - Contributions regarding the technical solutions for biological filtration within recirculating aquaculture systems, ISB INMA TEH' 2014, International Symposium, 30 octombrie - 1 noiembrie Bucureşti, ISSN 23444118(2014) 
[3]. Crab R., Avnimelech Y., Defoirdt T., Bossier P., Verstraete W. - Nitrogen removal techniques in aquaculture for a sustainable production, Aquaculture, Elsevier, vol. 270 (14), p. 1-14, (2007)

[4]. Cristea V., Grecu I., Ceapa C. Recirculating Aquaculture Systems Engineering, Ed. Didactical and Pedagogical R.A. Publishing, Bucharest, (2002) .

[5]. Malone R.F., Pfeiffer T.J. Rating fixed film nitrifying biofilters used inrecirculating aquaculture systems, Aquacultural Engineering, Elsevier, vol. 34 (3), (2006)

[6]. Pop A., Ştefanov C., Andrei S.G. Modular biofilter for recirculating aquaculture systems, Patent Application A01435 / 22.12.2011, INMA Bucharest, (2011)

[7]. Ştefanov C., Technical equipment for biological water filtration for superintensive fish growth in recirculating aquaculture systems (Biological Filter 2.4), (2011)

[8]. Ungureanu N., Vlăduţ V., Istrate I., Zăbavă B., Tociu C., Ferdeş M., Dincă M. Advanced electrochemical treatment of the wastewater from cattle farm, PROCEEDINGS OF THE 47 INTERNATIONAL SYMPOSIUM ON AGRICULTURAL ENGINEERING "Actual Tasks on Agricultural Engineering", pag. 147-158, Opatija - Croaţia, http://atae.agr.hr/, (2019);

[9]. Ungureanu N., Vlăduţ V. ${ }^{*}$, Voicu gh. - Water Scarcity and Wastewater Reuse in Crop Irrigation, SUSTAINABILITY 12(21), 9055; https://doi.org/10.3390/su12219055, (2020);

[10]. Zăbavă B., Ipate G., Voicu Gh., Dincă M., Ungureanu N., Ferdeş M., Vlăduţ V. Smart system to monitor wastewater treatment based on Raspberry Pi computer, PROCEEDINGS OF THE 47 INTERNATIONAL SYMPOSIUM ON AGRICULTURAL ENGINEERING "Actual Tasks on Agricultural Engineering", pag. 159-166, 2019, Opatija - Croaţia, http://atae.agr.hr/, (2019). 